\title{
O livro tem volume?
}

\author{
Diego Rodrigues Belo \\ Programa de Pós-Graduação em Comunicação Social, \\ Universidade Federal de Minas Gerais, Brasil
}

DOI: https://doi.org/10.31492/2184-2043.RILP2020.37/pp.141-155

\section{Resumo}

Um fragmento de silêncio que ocupa as mãos e os olhos. O livro impresso convida não só a uma leitura silenciosa, bem como clama por um ambiente de escassos ruídos. Atividade íntima, exige concentração e dedicação do corpo-leitor. O projeto gráfico pode ser visto como estrutura pensante e de pensamento, favorece a circulação das ideias e serve como instrumento para a organização, consolidação e disseminação do conhecimento. Cumulativo, irreversível, sucessivo e cronológico, o saber configurado nos impressos se deve também a certa reverência e autoridade que conferimos a eles. É na comunhão provocada pelo ato de leitura que o livro pode ser tomado enquanto meio decisivo para o fomento das faculdades perceptivas e do pensamento. A partir deste artigo cada vez mais escasso na sociedade contemporânea - o silêncio - convoco Didi-Huberman para tratar sobre a complexa noção de "sintoma", seja em suas configurações visuais ou temporalidades. Proponho uma ideia de silêncio enquanto potencial sintoma do livro, instigando sua visualidade por meio de um sinal tipográfico - a "vírgula de perquirição". Com isso, objetivo examinar o inquietante "silêncio do livro" em relação à capacidade projetual do design gráfico construir espaços convenientes para ativar a imaginação e ação humanas.

Palavras-chave: cultura; design do livro; design gráfico; silêncio; sintoma.

\section{Abstract}

A fragment of silence that keeps the hands and eyes busy. The printed book not only invites you to read quietly but also beckons a low noise environment. An intimate activity, it requires concentration and dedication from the reader. The graphic project can be seen as one which evokes thought, favoring the circulation of ideas and serving as an instrument for the organization, consolidation and dissemination of knowledge. Cumulative, irreversible, successive and chronological, the knowledge configured in print is also due to a certain reverence and authority that we confer on it. It is in the communion generated by the act of reading that the book can be taken as a decisive means in the exercise of fostering perceptual and critical thinking abilities. And from this increasingly rare phenomenon in contemporary society - silence - I invoke Didi-Huberman to address the complex notion of "symptom", whether in its visual configurations or in its temporalities. I propose an idea of silence as a potential symptom of the book, stimulating its visuality by means of a typographic sign - the "inquiry comma". I aim to examine the uneasiness caused by the "silence of the book" in relation to the ability of graphic design projects to build convenient spaces that activate human imagination and action.

Keywords: book design; culture; graphic design; silence; symptom.

Como responder a tantas perguntas? Pablo Neruda pergunta mais que criança! Muitas perguntas parecem absurdas ou difíceis de responder. Elas têm um jeito diferente de ser e uma maneira de ver as coisas que ninguém tem. São tantas dúvidas que desconfio que elas não sejam para a gente responder. Acho mesmo que são para pensar. Divertidas ou até um pouco tristes, as frases fora do comum servem perfeitamente para a nossa imaginação. Ajudam a refletir sobre as coisas e o mundo, sobre nós humanos, sobre tudo. De onde o poeta tirou tantas perguntas? Será que foi das cabeças questionadoras de todas as crianças do mundo?

Alice Rocha Gonçalves, dez anos. Pablo Neruda, Livro das perguntas. 


\section{Abertura}

É Fazer silêncio. Estranha, paradoxal e reveladora expressão, já que evidencia o caráter artificial do termo. O silêncio é algo que se fabrica. Não necessariamente pejorativo, como quando se diz "comprar o silêncio" ou "vender o silêncio". Contudo, ironia, o silêncio pode se quebrar. E ao ser rompido, talvez, é que melhor se revela.

Volta e meia, divago em instigante observação: guardo na estante da biblioteca um exemplar do Livro das perguntas, de Pablo Neruda (2008). Ora, mas não residiria na própria ideia de livro a noção de artefato que enquadra e questiona determinado aspecto da realidade circundante e de nossa relação com o mundo? Nesse sentido, o livro, enquanto forma, não incorpora, convoca e abre possibilidades de diálogo com o usuário-leitor que compartilha daquele determinado espaço gráfico? Não seria, por isso mesmo, todo e qualquer livro um objeto de perguntas? E mais: o título do livro de Neruda não configuraria um pleonasmo dos mais curiosos?

Pretendo, neste trabalho, observar o objeto livro a partir de uma noção do silêncio. Especificamente, questiono o projeto de design gráfico do livro enquanto meio articulador de diversificados diálogos socioculturais. Em sentido amplo, pretendo pensar sobre o silêncio tomando como campo de investigação o livro impresso. A proposta que almejo discutir localiza o livro dentro de um estreito limiar de mediação no qual diferentes atores sociais interagem. Como provocação, na expectativa de contribuição teórica acerca do complexo debate que envolve os mecanismos articuladores entre design gráfico e cultura, proponho análise que estabelece o livro a partir de um enredo potencialmente infinito. Isto é, ao passo em que o livro dirige uma pergunta, um questionamento, uma investigação para o mundo, ele convoca os respectivos interlocutores a restituírem determinados sentidos que, a partir do livro - ou com o livro -, foram estimulados.

Com isso, almejo atribuir à noção de "silêncio do livro" uma fração específica, profundamente instável, decorrente da interação perceptiva entre usuário-leitor e livro. Para tanto, ofereço, a título de metáfora argumentativa, um sinal tipográfico que seria capaz de traduzir o exato instante em que o silêncio do livro tornase visível. Recorro ao universo da linguagem escrita (proficiência própria dos livros) para representar um limiar, o instante em que há algum grau de suspensão do entendimento sobre com quem está a prerrogativa da comunicação das mensagens. Trabalho a ideia do livro enquanto um objeto-modelo de investigação, consolidado culturalmente, e de convite à reflexão; nunca estanque, no mais das vezes um exercício pluridimensional da imaginação. 
Assumo posição notadamente especulativa e provocativa justamente com o intuito de fomentar discussões e ampliar o repertório de possibilidades analíticas deste emaranhado em que o livro está enredado, nas múltiplas relações existentes entre o objeto livro e as articulações dele decorrentes - sejam elementos físicos, simbólicos ou culturais -, especialmente àquelas configuradas pela práxis de design gráfico.

Considero o silêncio por uma de suas conotações positivas, condição que acredito favorecer a concentração e a atenção necessárias à leitura de um livro. Claro que uma abordagem mais abrangente deveria considerar diversos outros silêncios, tais como os exemplificados por David Lapoujade.

Só há silêncio num espaço de fala. Certamente se pode supor que a fala vem sempre depois do silêncio, que ela vem cobrir, romper e traduzir o mundo silencioso das coisas. Mas, em realidade, só as percebemos silenciosas porque vivemos no interior da linguagem. E é justamente no interior da linguagem, entre os seres falantes, que se encontra uma grande variedade de silêncios: há o silêncio de quem escuta, de quem se recusa a falar. Há silêncios cúmplices, silêncios desaprovadores, silêncios ameaçadores, silêncios repousantes, e o silêncio das coisas materiais participa de todos esses silêncios. (Lapoujade, 2014, p.151)

$\mathrm{O}$ que reforça a tese inicial deste trabalho. O silêncio é um conceito invariavelmente produzido pela ação humana. E, como tal, pode ser percebido no projeto de design gráfico de um livro, servindo para atrair e conduzir as experiências dos usuários-leitores.

\section{O projeto gráfico}

Penso sobre o livro. Investigo, portanto, o peso que o livro exerce sobre o corpo-leitor. Um fardo cultural, um aparato técnico e sensível ao alcance dos olhos e das mãos, um atalho para a tomada de posição. Dentre as textualidades que enredam livro e cultura, focalizo aquelas concernentes ao projeto de design gráfico. O projeto gráfico - inerente a todo e qualquer livro - direciona o meu olhar enquanto pesquisador, procurando os percursos planejados pelo designer gráfico e as potenciais rotas que podem ser estabelecidas pelo usuário-leitor.

A aparência do livro possui uma linguagem que lhe é peculiar. No folhear, página a página, procuro decifrar a estrutura gráfica que o sustenta e com ela aprendo a transitar. Atenção, imaginação e montagem se encontra tanto no livro com o qual interajo quanto no ambiente para onde sou lançado. $\mathrm{O}$ ato de leitura implica, portanto, em deslocamento. Tal jornada está subordinada à capacidade imaginativa do ser humano e também ao projeto de design gráfico, veículo que sustenta e direciona a experiência de leitura. 
Uma postura indagadora diante de um projeto gráfico impõe o questionamento: quais saberes - e a partir de quais sintomas (visuais, táteis, sinestésicos) - estariam configurados no artefato? O pensamento é convocado a refletir criticamente sobre como se processa a simbiose entre o usuário e o utilitário e o porquê dessa comunhão ser tão profundamente relevante no contexto em que os seres humanos constroem e desenvolvem o próprio meio de existência. Quer dizer, de certa maneira, o design gráfico ocupa espaço não só como artifício de comunicação; pode evidenciar um instrumento de uso diversificado e também de questionamento generalizado dos poderes, dos saberes e dos corpos. Sendo assim, posso tomá-lo como uma ferramenta, documento sociocultural das possibilidades de usos e das potencialidades dos saberes.

Quando observado, o livro se mostra força expressiva e sensível, que não bastasse servir de suporte para a existência física das ideias, práticas e discursos humanos, recorre principalmente à linguagem tátil e visual - perceptível a partir dos recursos de design gráfico - para forjar um artefato de valor cultural, historicamente localizado no tempo e no espaço social. Enquanto meio, o livro é um sistema completo. Todavia, se encontra aberto às mais variadas articulações simbólicas. A leitura, em particular, e a percepção, de modo geral, possuem caráter nômade, de impressões e interpretações desterritorializadas. O livro, por sua vez, evoca diferentes e intrínsecas capacidades subjetivas de recortar, deslocar, enquadrar, remontar, ressignificar as partilhas do sensível.

Tal saber-movimento diz do encontro entre o usuário-leitor e a "mancha tipográfica" - termo que expressa a relação entre o formato da página e a ocupação do bloco de texto -, os respectivos ritos de passagem e comunhão. Com isso, concebo à medialidade do livro uma posição peculiar, que ultrapassa o caráter de suporte subsidiário para múltiplas formas comunicacionais - para citar algumas, literatura, arte e ciência - pois assume, ele próprio, protagonismo nos aspectos sensoriais despertados a partir das trajetórias gráficas percorridas.

A importância do tema não se limita às configurações técnicas ou estéticas, já que transborda para o entorno cultural, produto de uma consciente ação humana, em grande medida determinada pela convergência de aspectos técnicos, sociais, econômicos, estéticos, psicológicos, dentre outros. Persigo o entendimento de Janssen (2004), para quem a história do livro é uma disciplina que compõe a história da cultura em geral. Interesso investigar o projeto gráfico como meio para gravação e transmissão de mensagens, ao mesmo passo que um operador capaz de conduzir influências capturadas, interpretadas, transformadas e retransmitidas.

Afinal, o visível sempre possui, nos termos de Gonzalo Abril (2012), uma estrutura invisível, capaz de regular a percepção visual. Toda imagem carrega 
consigo aquilo que não se vê, condicionada a partir do que se deseja ver, daquilo que se sabe e se crê e também do que se faz com o que se vê. A mancha, assim como o grid, a hierarquia, o ritmo, são componentes estruturais de todo projeto gráfico e, por vezes, os tomamos de modo pouco crítico ou sem problematizar suas abrangências socioculturais. Ainda que subsidiário e pouco rastreável no livro publicado, preserva a força imaginativa daquele que o projetou, é devedor do imaginário social que, por sua vez, indica os modos de configuração ou decodificação das próprias imagens. E sendo assim, enreda indivíduos, sociedade, imagem, imaginário, percepção e o meio livro em um só corpo. Temos aqui, precisamente, o que Belting (2007b) designa como elementos associados ao "visual", numa clara distinção em relação ao "visível".

\begin{abstract}
Ocorre uma metamorfose quando as imagens vistas se transmutam em imagens recordadas que, a partir daí, encontram um novo lugar no nosso arquivo imaginal. Começamos por despojar do seu corpo as imagens exteriores que "chegamos a ver", para, num segundo momento, de novo as corporalizarmos: tem lugar um intercâmbio entre o seu meio-suporte e o nosso corpo que, por seu lado, constitui um meio natural. ...A impressão imaginal que recebemos através do meio guia e modela a atenção que prestamos às imagens, visto que um meio tem não só uma qualidade físico-técnica, como também uma forma temporal-histórica. Nossa percepção está sujeita à mudança cultural, apesar de os nossos órgãos sensoriais, desde tempos imemoriais, não terem sido modificados ${ }^{1}$. (Belting, 2007b, p.27)
\end{abstract}

Reconhecer o design gráfico como sugestão antropocêntrica de direção envolve discutir as formas de conduzir o exercício do olhar, do tocar, do perceber e do pensar. Os projetos de design gráfico, a partir das características formais e simbólicas, sugerem percursos, habitam a cultura e se tornam o nosso habitat. O projeto gráfico do livro é uma manifestação cultural ativa, de uso, e funciona como o término provisório de um complexo trajeto - uma cadeia infinita de contribuições, como uma narrativa que interpreta e prolonga os enredos anteriores.

Nesse sentido, antes de se tornar familiar para o usuário-leitor, o livro reivindica ser olhado e compreendido. Compreender, aqui, indicando uma relação de captura de alguns dos modos como o livro nos observa. O confronto atrai a atenção necessária para elaborar uma sensibilidade que se pressupõe precária e difusa, porém aberta ao relacionamento. $\mathrm{O}$ acesso não diz necessariamente da

1. Ocurre un acto de metamorfosis cuando las imágenes de algo que sucedió se transforman en imágenes recordadas, que, a partir de ahí, encontrarán un nuevo lugar en nuestro almacén personal de imágenes. En un primer acto despojamos de su cuerpo a las imágenes exteriores que nosotros "llegamos a ver", para en un segundo acto proporcionarles un nuevo cuerpo: tiene lugar un intercambio entre su medio portador y nuestro cuerpo, que, por otra parte, se constituye en un medio natural. [...] La impresión de la imagen que recibimos a través del medio almacena la atención que les dedicamos a las imágenes, puesto que un medio solamente tiene una cualidad físico-técnica, sino también una forma temporal histórica. Nuestra percepción está sujeta al cambio cultural, a pesar de que, desde los tiempos más remotos imaginables, nuestros órganos sensoriales no se han transformado. [Tradução do autor] 
disponibilidade de leitura, contudo indica o caminho como um problema que implica deslocar-se para conhecer.

\section{O volume do livro}

Se há silêncio no projeto gráfico do livro, ocorre justamente porque há um desejo secreto no usuário-leitor para estar nele abrigado e ser ouvido.

Depois de tudo o que já foi escrito sobre o livro, suas histórias e peripécias, o que procuro nesta investigação é argumentar que algo escapa à visada de grande parte das análises. O livro, enquanto objeto de pesquisa, carrega uma tradição consolidada e atravessada por muitos séculos. A ideia de que sua existência postula importância significativa para o ser humano não é nova; pode ser encontrada, com evidente destaque, em duas das religiões mais significativas de nosso tempo. A Bíblia e o Alcorão são consagrados, funcionam como alicerces fundamentais para ensinamento, pensamento, direcionamento de determinadas condutas. Entretanto, diante do entendimento de que a disposição dos elementos textuais na página e a própria existência física do artefato importam e significam, pretendo fazer crer que estudos sobre o livro padecem de incentivos que abarquem também essa perspectiva.

Mesmo que muitos pesquisadores já tenham se debruçado sobre a sociologia dos textos ou sobre produção, circulação e comercialização dos impressos, o design gráfico costuma ocupar um papel subsidiário em tais discussões. $\mathrm{O}$ que pode revelar ao menos duas possibilidades: a baixa influência do design gráfico para a constituição do livro ou, talvez, a incompreensão a respeito de sua importância para o tema. Prefiro apostar nesta possibilidade. Por isso, proponho inscrever o projeto gráfico do livro como parte integrante e relevante para expandir a compreensão sobre o assunto. E, com isso, estabelecer diretrizes que fomentem o debate entre uma suposta transitividade entre design gráfico, cultura e ser humano. A tendência é resistir às discussões já bastante reconhecidas e consolidadas, abrindo novos e diferentes flancos para se pensar a respeito do livro enquanto produto com profunda dimensão cultural. Uma perspectiva diversa, contudo atravessada pela curiosidade de se descobrir as implicações do design e da cultura no pensamento e ação humanos.

A história do livro impresso vem sendo construída nas últimas décadas a partir do que Janssen (2004) entende por “bibliografia analítica”. Envolve aspectos relacionados à produção do livro impresso, isto é, diagramação dos tipos, técnicas de impressão, prensas tipográficas, o substrato papel, dentre outras ferramentas e materiais. Contudo, o campo da bibliografia analítica começa a se abrir para o que o autor denomina "design tipográfico". Em adição à relevância da técnica de 
impressão na transmissão dos textos, passa a ganhar corpo a função do design gráfico desses mesmos textos, o que indica fundamentalmente a maneira como eles são projetados e lidos.

Incorporo a noção da existência de um "saber-movimento" nas manchas tipográficas. Conforme Didi-Huberman (Prefácio in Michaud, 2013b, p.19), "um saber em extensões, em relações associativas, em montagens, sempre renovadas, e não mais um saber em linhas retas, em corpos fechados, em tipologias estáveis". Do saber configurado no projeto gráfico do livro procuro uma fonte de imagens turbilhantes e centrífugas. Nesse sentido, reivindico no projeto de design gráfico sua atividade patológica. $\mathrm{O}$ encontro entre a lógica racional projetual e a ordem sensitiva do páthos, isto é, a fórmula patética warburguiana enquanto rastro para o entendimento e direcionamento constitutivo de como o silêncio no livro pode se revelar. Desse modo, surgiriam as bases para a compreensão da reciprocidade latente entre a vontade de saber - o ser humano - e o objeto de saber - o livro. A busca é pela abertura que possibilitaria identificar algumas das cadeias de tradução que operam no interior da linguagem do design gráfico.

Para o que cabe aqui avaliar, acredito ser possível interpretar uma certa noção do silêncio como modo de interação entre usuário-leitor e livro. Não no sentido da ausência de quaisquer barulhos. Antes pelo contrário, percebendo o livro como um armazém onde circulam silêncios e também muitos outros elementos de naturezas diversas. Como bem relatara John Cage, o silêncio não existe concretamente, se analisado na presença de um corpo humano vivo. No limite, o sistema nervoso e a circulação sanguínea farão ruídos suficientemente perceptíveis. E assim sendo, proponho entender, alicerçado em Georges Didi-Huberman, o silêncio como um dos possíveis sintomas do livro.

\footnotetext{
Será preciso, então, interrogar ainda o sentido, o que a palavra "sintoma" implica. Palavra difícil de apreender: ela não designa uma coisa isolada, nem mesmo um processo que poderíamos reduzir a um ou dois vetores ou a um número preciso de componentes. É uma complexidade de segundo grau. É outra coisa além do conceito semiológico ou clínico, mesmo que comprometa uma certa compreensão da emergência (fenomenal) do sentido, e mesmo que comprometa uma certa compreensão da pregnância (estrutural) da disfuncionalidade. Essa noção denota no mínimo um duplo paradoxo, visual e temporal, que nos permite compreender seu interesse para nosso campo de interrogações sobre as imagens e o tempo. (Didi-Huberman, 2015b, p.43)
}

Sintoma que prescreve o princípio básico da relação entre usuário-leitor e livro: sintonia. É na aparição do livro - e aqui tento seguir Didi-Huberman (2015b) que o silêncio sobrevém. O livro é objetal, um obstáculo que interrompe o curso do usuário-leitor. O que não implica em facilidade ou imediatismo comunicativo. 
Pois, conforme Didi-Huberman (2015b, p.44), o sintoma é anacrônico, incerto, "surge sempre a contratempo, tal como uma antiga doença que volta a importunar nosso presente. E, mais uma vez, segundo uma lei que resiste à observação trivial, uma lei subterrânea que compõe durações múltiplas, tempos heterogêneos e memórias entrelaçadas".

O mundo contemporâneo - ao menos se considerado no contexto das grandes cidades ou das comunidades intensamente conectadas aos gadgets - se estrutura na contramão da noção de sintonia. Os estímulos são tão intensamente variados que se torna uma árdua missão encontrar a "tranquilidade" - uma espécie de encaixe - necessária para a fruição de um livro. Nesse sentido, entendo com Jankélévitch (2018, p.201), que "o silêncio, por um lado, faz aparecer o contraponto latente das vozes passadas e vindouras, ofuscado pelo tumulto do presente, e, por outro, revela a voz inaudível da ausência, recoberta pela algazarra ensurdecedora das presenças".

Ainda assim, vivenciamos por vezes experiências de leitura capazes de neutralizar minimamente as interferências externas ao livro, por assim dizer. Mesmo que não seja particularmente simples ou cotidiano. Comparo a uma prática singular e anedótica: ao conduzir um automóvel e procurar um endereço simultaneamente, abaixamos o volume do rádio. Do que é possível sustentar que o corpo humano possui uma capacidade sensível. Isto é: os sentidos trabalham bem em conjunto até certo grau. Para determinadas atividades, contudo, a atenção requerida é tão intensa que o corpo praticamente anula determinados sentidos em favorecimento de outros. No ato de leitura, por exemplo, recorremos principalmente à visão e ao tato. Excessivos estímulos sonoros, quando há, podem roubar parte da banda sensorial dedicada à atenção e percepção do usuário-leitor. Por isso, o contrário é tão revelador: quando se procura anular algum sentido perceptivo, um dos efeitos passa pela intensificação de outro. Isto é: em ambientes mais controlados e convidativos ao ato de leitura, destacam-se as interações e trocas peculiares decorrentes da relação entre livro e indivíduo.

O diálogo, além de íntimo, é profícuo. Quando é a página que imposta uma entonação, o leitor se cala. Ou não. A cacofonia produz também uma lógica de leitura. De todo modo, seguindo Quignard (2014, p.150), "o cuidado com a disposição das formas na página busca retraçar a ficção de uma enunciação impossível". Da impossibilidade latente, surgem múltiplas e diferenciadas tentativas de interpretação e compreensão. Daí, é razoável afirmar: com tantas maneiras possíveis de se estimular e construir o pensamento, temos à disposição um amplo repertório para ser explorado pelos projetos de design gráfico. Ao fim e ao cabo - parafraseando Ferreira Gullar, diga-se, tradutor da edição brasileira 
do Livro das perguntas -, o design, as ferramentas, a imaginação, o livro são forjados justamente porque a vida é insuficiente. Ao que pode ser acrescentado que as coisas ricocheteiam no mundo e em nós mesmos. Por isso se fazem tão presentes e necessárias à construção da cultura, já que estão intrinsecamente relacionadas aos modos que constituímos o próprio viver.

\section{A vírgula de perquirição}

O ponto de interrogação [?] é um sinal gráfico que, na linguagem escrita, indica uma entonação, isto é, modulação de uma sentença interrogativa e a separação entre unidades. Promove clareza, distinção e algum grau de emulação da oralidade a partir do texto impresso. Interessante notar que, por exemplo, a língua espanhola preserva o ponto de interrogação invertido [i] antes da pergunta justamente para advertir previamente ao leitor da correta entonação da frase num texto impresso.

Não possuímos formalizado, porém, um marcador específico que indica uma pergunta dentro de uma oração. Quero dizer: mesmo que um determinado raciocínio seja contínuo, o ponto de interrogação vai demarcar e interromper a articulação do discurso. Contudo, consta em Unger (2016) a curiosa tentativa de incorporar tal caractere tipográfico ao vocabulário comum, o que auxiliaria a indicar, justamente, perguntas que ocorrem no meio de frases. A solução não foi adiante, mas a ideia que carrega me foi útil para conduzir a proposta que ofereço ao pensar numa das possíveis relações entre silêncio e livro.

Ao trabalhar um caractere tipográfico, parto da noção do livro enquanto pergunta (portanto, equivalente, na essência, a um ponto de interrogação dirigido ao espaço sociocultural), com a diferença de que não bastaria apenas lançar a pergunta, já que a ideia do livro, seguindo essa posição, postula um questionamento aberto, contínuo e espacialmente difuso. O que, talvez, o ponto final que está implicitamente contido no ponto de interrogação não dê conta de contemplar. Por isso, a partir e em contraposição ao ponto de interrogação, sugiro e denominarei o sinal gráfico como "vírgula de perquirição".

Claro, trato unicamente como elemento metafórico e desconsidero as mais diversas implicações decorrentes da inserção de um novo símbolo gráfico no vocabulário corrente. Por mais atraente, sedutora e excêntrica que pareça a proposta, tal implicação incorre demasiado complexa para a discussão que aqui se propõe. Sem dúvida, subsidiariamente agrego uma oportunidade para refletir acerca do repertório e da consolidação dos códigos linguísticos e de como esse é um aspecto que tomamos como estável, mas é passível de aberturas, manipulações, até ao ponto de requisitar novas formas de expressão verbal e visual. 
Figura 1. A vírgula de perquirição.

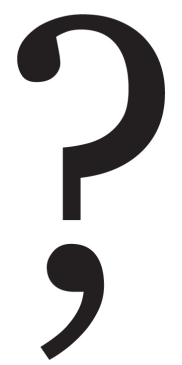

Proponho, então, observar o livro num determinado instante, dentro de um amplo percurso sociocultural. É o exato momento em que se interpõe, interrompe um trajeto, e pode potencialmente modificá-lo, abrindo novas possibilidades de travessias. De modo claro, argumento que é no encontro do livro com o usuárioleitor que a pausa se dá, uma suspensão momentânea do espaço-tempo, espécie de vazio semântico que oferece a oportunidade para um fôlego e imediatamente a comunhão entre os corpos. O que pressupõe, por ambas as partes, uma tomada de decisão.

Não é descartável, também, dentro do entendimento da vírgula de perquirição enquanto instrumento para refletir acerca do silêncio no livro, em como a pausa que indaga é também uma emboscada, uma armadilha para capturar a atenção do usuário-leitor. Por outro lado, dialeticamente, é o próprio interlocutor quem dirige um questionamento ao livro. E essa é uma boa maneira de entender o processo mútuo de atração entre os corpos (humano e livresco) e a volúpia com que o usuário-leitor estende suas mãos e avança em direção ao livro.

Há algo que se desprende do livro como imagem. Uma sedutora imagem. A mancha tipográfica é uma imagem - um dos textos visuais do livro - que se desloca, parte do meio e vai procurar refúgio no corpo-leitor. Para auxílio no alicerce investigativo, algumas noções conceituais disponibilizadas por Georges Didi-Huberman são requeridas, principalmente a partir do trabalho de Aby Warburg. O intuito é incorporar à discussão científica chaves analíticas consistentes, porém pouco exploradas no âmbito do design gráfico. Com isso, investigar o silêncio gerado por, digamos, uma espécie de dúvida, uma curiosidade sensorial - sintoma ilustrado na figura da vírgula de perquirição. Quer dizer, a ideia é constituir um eixo articulador entre o meio (livro em si), a respectiva mancha tipográfica disponibilizada pelo projeto gráfico e o usuário-leitor que irá recepcionar as mensagens. 
Se possível for, parafraseio Didi-Huberman para dizer que a potencialidade comunicativa da mancha tipográfica é como uma e-moção: nunca diz eu, pois se dirige sempre para fora do livro. Tampouco está em mim mesmo, usuário-leitor, já que vagueia à procura de acoplagens, metamorfoses. Para Didi-Huberman (2016), o páthos é um movimento para fora de si. Ao mesmo tempo que se encontra no sujeito, foge à razão. E se encontra ainda fora do eu, na medida em que o atravessa para depois se perder novamente. Por isso, é algo que nos possui, mas que somos incapazes de possuir por inteiro, já que é, em grande medida, desconhecido por todos nós. Nesse sentido, é como um espectro - uma mancha-, por vezes silencioso e a vagar em busca de corpos onde possa penetrar, inquietar e sensibilizar.

De mais a mais, livros requisitam ser habitados por seu respectivo leitor, indicam percursos, dividem e organizam as informações. Assim como uma edificação não se presta apenas ao abrigo, seria redutor analisar livros apenas por seus aspectos linguísticos, por assim dizer. Mesmo que exista um enfoque mais tradicional nas características formais e funcionais de um livro, devem ser consideradas suas expectativas enquanto instrumento comunicacional de diferentes amplitudes e qualidades culturais. Há outros textos, mais ou menos evidentes, presentes no livro. Reivindico a relevância de um deles: o silêncio.

O livro pode se prestar como meio indutor de curiosidades múltiplas, um lugar para se perder, já que nós, seres humanos, somos atraídos justamente por aquilo que não conhecemos. A própria dialética entre interior/exterior, dentro/ fora, conhecido/desconhecido, eu/outro indica uma capacidade de desenvolver experiências afetivas que geralmente o corpo humano não é capaz de alcançar sozinho. Carecem de uma existência espacialmente configurada por um livro, por exemplo. Um espaço que se destina à produção e circulação do conhecimento possibilita estimular o desenvolvimento de temas pelo maior número de perspectivas possível. É na pluralidade de abordagens que as reflexões florescem, a diversidade é um relevante insumo para o questionamento de padrões consolidados e quebra de estereótipos banais e estéreis. Nesse sentido - e aqui procuro delinear o entendimento que subsidia o desenvolvimento deste trabalho -, a vírgula de perquirição é um modo de demonstrar como a prática de design gráfico seria capaz de construir lugares convenientes para ativar o pensamento.

\section{5. À guisa de fechamento}

As articulações simbólicas colocadas em questão nesta investigação tomam forma a partir da sintaxe do design gráfico, processos técnicos estabelecidos a partir de elementos constitutivos do projeto gráfico, tais como hierarquia, formato 
da página, ritmo, tipografia. Precisamente, o ponto de entrada se dá por aquilo que se convencionou denominar "mancha tipográfica". O termo não deixa de ser um jargão profissional, contudo capaz de sintetizar as mais variadas formas pelas quais os diferentes elementos de um projeto gráfico são distribuídos dentro de uma página.

É interessante ressaltar que o que caracteriza um livro não é simplesmente o pensamento estruturado pelo alfabeto, pensamento lógico e processual, informado pelo discurso. A anatomia do livro, por si, permite uma ampla pesquisa científica. Há estruturas que mimetizam o corpo humano. Podemos observar o lombo, a barriga, o pé, a folha de rosto, as faces ou o espelhamento das páginas. Sua aparência formal é normativa. Parte de uma forma geométrica rigorosa, simétrica. A construção perspicaz e o aspecto elementar do livro está inscrito em sua dobra. A dobra é o princípio da lombada, que por sua vez indica a terceira dimensão, já que a superfície de uma folha se torna, articulada e sobreposta, volume.

Penso que o livro deve ser entendido como um corpo vivo. Dele, pulsam imagens ávidas por cérebros anfitriões. A memória recepciona e sintetiza as imagens capturadas pelos atos perceptivos deste corpo-caçador. Tais atos não se dão às cegas, já que é das capacidades sensoriais de que se trata o confronto. Há um instante em que o projeto gráfico do livro se liberta do contexto da vida cotidiana e penetra no campo técnico da prática profissional. É onde residem aspectos particulares do fazer - as causas, as motivações, os acasos. O projeto elabora diferentes camadas de inteligibilidade e intertextualidade, estabelece consonantes (por vezes, contrárias) relações com o espaço, o tempo e o contexto em que se coloca.

A leitura, por seu turno, nunca está dada. Ao mesmo passo em que se detém na unidade formal delimitada pelo espaço físico do livro, também transita descontinuamente pelo repertório do corpo-leitor, seja construindo paralelismos concordantes ou confrontantes com as textualidades do objeto-livro.

A partir de ambas perspectivas, constata-se que o espaço projetado configura e condensa uma noção de tempo. Tempo da ordem do fabricar, do consumir, da historicidade que regula uma categoria entendida como "livro" e da duração própria da matéria. Um novo projeto de livro se distingue de seus pares, contudo se integra aos demais. É um diálogo às margens do infinito, estabelecido pela relação entre aqueles que existiram, os que se interpõem no presente e todos os outros que virão.

Bringhurst (2005) também se dedica no Elementos do estilo tipográfico à discussão das implicações matemáticas, formais, musicais de um espaço gráfico. Há notório interesse em sistematizar algumas proporções recorrentes, justificadas 
por serem confortáveis para as mãos, agradáveis aos olhos e à mente. Há milhares de anos, a explanação sustenta, projetistas configuram espaços visuais - sejam eles livros ou mesquitas - e partem de figuras geométricas simples. E mesmo deslocados entre si no tempo e no espaço, preservam curiosa regularidade. Inclusive, certas proporções vão muito além do âmbito humano, sendo também proeminentes na natureza. Os intervalos, as diferenças, os ritmos e as harmonias que Bringhurst (2005) demonstra dizem, claro, da fluência e da virtude do projeto gráfico. Contudo, é digno de encanto observar formas singulares, duráveis, atravessando a história, o espaço e o tempo, resistindo aos mais diversos usos e tecnologias. Para além da geometria pura, procuro observar na flexibilidade de diferentes composições de uma página o senso de direção implicado, em como o corpo-leitor se coloca em relação ao projeto e para onde ele pode ser levado.

Discutir sentidos e imagens que se desprendem do design do livro, os modos como se insinuam, pode revelar muitas de suas potencialidades. Entendo que o livro incorpora aspectos culturais relevantes. Concomitantemente, estabelece determinados modos de uso e funcionamento, condições para o compartilhamento e produção de saberes diversos.

Em sentido amplo, o presente trabalho procura contribuir para desvelar as implicações do design gráfico e da cultura no pensamento e ação humanos. Se, como aqui se propõe, o silêncio do livro puder ser compreendido como a suspensão do entendimento - a partir da oscilação não resolvida entre o estranhamento e a curiosidade -, é possível argumentar que tal relacionamento se dá coberto de tensões. É no movimento criado pelo uso imaginativo do livro que circunscreveria, então, para lembrar Agamben (2012, p.60), "um espaço em que não pensamos ainda, no qual o pensamento se torna possível somente por meio de uma impossibilidade de pensar". A imaginação atua como força no impulso para a descoberta do desconhecido. O que leva a refletir que, dentre todos os modos que a linguagem comunica, o interrogativo é o que melhor se oferece ao escrutínio subjetivo do mundo sensível.

A vírgula de perquirição, portanto, enquanto imagem mental tomada em consonância com a presente análise, elabora o argumento de que os projetos gráficos dos livros - ao articularem elementos tais como ritmo e proporção; harmonia e contraponto; formas e dispositivos estruturais; símbolos não alfabéticos; e, as proporções e as formas que governam o desenho de uma página (Bringhurst, 2005) - exercitam e sobrevivem às partilhas do sensível, pois convocam e embaralham experiências inesgotáveis. Contribuem para elevar a página à potência do espaço sideral. O livro traz em seu próprio corpo sentidos expansivos, uma vez que escapam de sua limitação formal e extravasam para a 
existência cotidiana do usuário-leitor. O uso e a leitura dos livros escondem na passividade aparente uma poderosa atividade imaginativa, que diz muito sobre o corpo humano, bem como suas respectivas perquirições e peregrinações em relação ao ser, ao espaço e ao tempo.

\section{Referências}

Abril, G. (2007). Aquí va a ver más que palabras. CIC. Cuadernos de Información y Comunicación, 12, pp.7-9. Disponível em: bit.ly/2xOP2F4. Acesso em 10/07/2019.

. (2012). Tres dimensiones del texto y de la cultura visual. IC - Revista Científica de Información y Comunicación, 9, pp.15-35. Disponível em: bit.ly/2Ln9OUM. Acesso em 10/07/2019.

Agamben, G. (2012). Ninfas. São Paulo: Hedra.

Belting, H. (2006). Imagem, mídia e corpo: uma nova abordagem à iconologia. Disponível em: goo.gl/SxYFsB. Acesso em 10/07/2019.

. (2007a). A verdadeira imagem. Porto: Dafne Editora. (2007b). Antropología de la imagen. Buenos Aires: Katz Editores.

Bringhurst, R. (2005). Elementos do Estilo Tipográfico. São Paulo: Cosac Naify.

Carrión, U. (2011). A nova arte de fazer livros. Belo Horizonte: C/ Arte.

Certeau, M. (1994). A invenção do cotidiano: 1. Artes de fazer. Petrópolis: Vozes.

Didi-Huberman, G. (2009). Ser crânio: lugar, contato, pensamento, escultura. Belo Horizonte: C/Arte. . (2010). O que vemos, o que nos olha. São Paulo: Editora 34.

. (2012, novembro). Quando as imagens tocam o real. Pós, v.2, n.4, pp.204-219. goo. gl/ThfJL9. Acesso em 10/07/2019.

. (2013a). A imagem sobrevivente: história da arte e tempo dos fantasmas segundo Aby Warbug. Rio de Janeiro: Contraponto.

. (2013b). Prefácio in Michaud, P-A. Aby Warburg e a imagem em movimento. Rio de Janeiro: Contraponto.

. (2013c). Diante da imagem: questão colocada aos fins de uma história da arte. São Paulo: Editora 34.

. (2015a). A semelhança informe: ou o gaio saber visual segundo Georges Bataille. Rio de Janeiro: Contraponto.

. (2015b). Diante do tempo: história da arte e anacronismo das imagens. Belo Horizonte: Editora UFMG.

. (2016). Que emoção! Que emoção?. São Paulo: Editora 34.

; Gisinger, A. (2017, outubro). Compreender por meio da fotografia. ZUM \#13, pp.86103.

Flusser, V. (2007). O mundo codificado - Por uma filosofia do design e da comunicação. São Paulo: Cosac Naify. 
. (2018). Filosofia da caixa preta: ensaios para uma filosofia da fotografia. São Paulo:

É Realizações.

Jankélévitch, V. (2018). A música e o inefável. São Paulo: Perspectiva.

Janssen, F. A. (2004). Technique et design in the history of printing. 't Goy-Houten: Hes \& De Graaf Publishers.

Hara, K. (2012). White. Zurich: Lars Müller Publishers.

Lapoujade, D. (2014). O inaudivel - uma política do silêncio. In: Novaes, A. (Org.) Mutações: o silêncio e a prosa do mundo. São Paulo: Edições Sesc São Paulo.

Manguel, A. (1997). Uma história da leitura. São Paulo: Companhia das Letras.

Melot, M. (2012). Livro,. Cotia: Ateliê Editorial.

Neruda, P. (2008). Livro das perguntas: Pablo Neruda. São Paulo: Cosac Naify.

Novaes, A. (Org.) (2014). Mutações: o silêncio e a prosa do mundo. São Paulo: Edições Sesc São Paulo.

Proust, M. (2016). Sobre a leitura seguido do depoimento de Céleste Albaret a Sonia Nolasco-Ferreira. Porto Alegre: L\&PM.

Quignard, P. (2014, novembro). Pagina. serrote \#18. pp.147-155.

Rancière, J. (2009). A partilha do sensivel: estética e politica. São Paulo: EXO experimental org.; Editora 34.

Steiner, G. (2018). Aqueles que queimam livros. Belo Horizonte: Editora Âyiné.

Turrer, D. (2002). O livro e ausência de livro em Tutaméia, de Guimarães Rosa. Belo Horizonte: Autêntica.

Unger, G. (2016). Enquanto você lê. Brasília: Estereográfica.

Warburg, A. (2015). História de fantasma para gente grande: escritos, esboços e conferências. São Paulo: Companhia das Letras. . (2018). A presença do Antigo. Campinas: Editora Unicamp.

Data receção: 11/09/2019

Data aprovação: 24/03/2020 